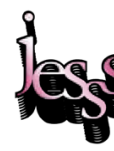

\title{
BIOMASS PRODUCTION AND TREATMENT OF KITCHEN WASTE WATER WITH NOSTOC MUSCORUM-A POTENTIAL BIOFERTILIZER
}

\author{
Tartte VIJAYA $^{1^{*}}$, Kalla Chandra MOULI ${ }^{2}$ and Sistla Durga Srinivasa MURTHY ${ }^{3}$ \\ ${ }^{1}$ Associate Professor, Dept. of Botany, Sri Venkateswara University \\ (Tirupati-517 502, Andhra Pradesh, India) \\ E-mail: tarttevijaya@yahoo.co.in \\ 2 Dept. of Biotechnology, Sri Venkateswara University \\ (Tirupati-517 502, Andhra Pradesh, India) \\ E-mail: bennypaulmouli@gmail.com \\ 3 Professor, Dept. of Biochemistry, Sri Venkateswara University \\ (Tirupati-517 502, Andhra Pradesh, India) \\ E-mail: sdsmurthy@rediffmail.com
}

\begin{abstract}
Kitchen waste water emerging from Tirumala hills, a world famous piligrim centre was used as a source of nutrients for cultivation of Nostoc muscorum. A complete randomized design (CRD) was created for the experiment which was performed on BG-11 medium, $100 \%$ kitchen waste water $(100 \% \mathrm{KW})$ and $75 \%$ kitchen waste water $(75 \% \mathrm{KW})$. The physicochemical properties of kitchen waste water and the yield of biomass were determined from the cultures harvested every three days for a period of 15 days. After cultivation the kitchen waste water met the standards of safe discharge in India. The organisms could able to remove maximum of $98 \%$ of contaminants during its growth in waste water. The highest production of biomass was achieved in BG-11 medium followed by $100 \% \mathrm{KW}$ and $75 \% \mathrm{KW}$.
\end{abstract}

Key words: Kitchen waste water, nutritional value, physicochemical properties, Nostoc muscorum, biomass.

\section{INTRODUCTION}

Treatment of waste water to remove unwanted nutrients using microorganisms has been widely applied throughout the world. Being the base for all food chains and primary production, aquatic phytoplankton play a key and indispensable role in cycling of elements and pollutants in any ecosystem. Cyanobacteria have a great deal of potential as a source of biofertilizer and biofuel ${ }^{1)}$. Recently, there has been increasing interest about using cyanobacteria as pollution control agents since they possess many advantages over the microorganisms isolated from soil. Some of the important advantages of using blue green alage such as Nostoc muscorum include relative safety of the microorganism, the efficient removal of the nitrogen and phosphorous nutrients, rapid growth rate and the ability to utilize the resulting organism as a biofertilizer for fixing atmospheric nitrogen. Tirumala hill region is located
$3200 \mathrm{ft}$ above the sea level in Chittoor District of Andhra Pradesh, India. It is visited by an average of one hundred thousand devotees per day. The process of cooking for such a large number of people in one place generates enormous amount of waste water from kitchen. Kitchen waste water has received relatively little attention although it can make a significant contribution to the polluted stream especially from dining facilities in large institutions and organisations. It is rich in nutrients like nitrogen, phosphorous, fats, proteins, carbohydrates etc ${ }^{2)}$. Culturing of Nostoc muscorum as a source of biofertilizer using inorganic culture media is relatively expensive because of the need to provide a full complement of nutrients. Low cost alternative such as waste water evaluated as a more cost effective method of producing biofertilizer. In addition cultivation of Nostoc muscorum improves water quality by reducing the waste water nutrient levels. Cultivation and treatment of sago starch factory waste water by Spirulina ${ }^{3)}$, pig waste water 
by Scenedesmus obliques ${ }^{4)}$, fish farm effluent by Phormidium bohneri ${ }^{5)}$ high strength organic waste water by Rhodobacter sphaeroides and Chlorella sorokiniana ${ }^{6}$, poultry slaughter house waste water by Rhodopseudomonas geltinosus ${ }^{7)}$ is well documented. The present study is aimed to compare the biomass production of Nostoc muscorum at $100 \%$ and $75 \%$ dilutions of kitchen waste water and to know the percent of nutrients removed in both the dilutions after harvesting the biomass.

\section{MATERIALS AND METHODS}

Twenty five liters of kitchen waste water emerging on Tirumala hills from food and dish washing was collected. This waste water was placed in $100 \mathrm{~L}$ cement tanks and allowed to ferment for 2 weeks at $32^{\circ} \mathrm{C} \pm 1^{\circ} \mathrm{C}$ under aerobic conditions with periodic stirring for microorganisms to breakdown the solid organic wastes. The liquid portion was filtered through 80 micron net filter after complete break down of solid partilces. The filtrate was taken for determination of temperature, $\mathrm{pH}$, dissolved oxygen (DO), biological oxygen demand (BOD), chemical oxygen demand (COD), ammonia nitrogen $\left(\mathrm{NH}_{3}-\right.$ $\mathrm{N})$, nitrate nitrogen $\left(\mathrm{NO}_{3}-\mathrm{N}\right)$, nitrite nitrogen $\left(\mathrm{NO}_{2}-\right.$ $\mathrm{N})$, total kjeldhal nitrogen (TKN) as per the methods described in "Standard methods for the examination of water and wastewater American Public Health Association ${ }^{8)}$. Total phosphorous (TP) content was determined by persulfate digestion method ${ }^{9)}$. The solid phase was used as a source of nutrients for growth of tropical medicinal plants (data yet to be published). This filtrate or $100 \%$ solution $(100 \% \mathrm{KW})$ was diluted to $75 \%$ with tap water to compare the growth of N.muscroum at lower dilutions of kitchen waste water. Greater dilutions were found to produce significantly lower growth rates, so only $100 \%$ and $75 \%$ solutions were used in this study.

Cultures of Nostoc muscorum were obtained from Biotechnology Research Center, Tirupati, A.P, India. The cyanobacteria are mostly associated with bacteria that live symbiotic relations, since bacterial contamination in the miscellaneous sheath of cyanobacteria can affect the results leading to articrafts. During the presentstudy, the selected species was provided as axenic culture. However, before using the organism for growth and bioremediation its axenity was checked using agar phototactic response method ${ }^{10)}$. The organism was cultured in standard BG-11 broth as out lined by ${ }^{11}$ in a 2 liter bottle and allowed to grow for 10 days until the optical density at $560 \mathrm{~nm}$ reached $1(\mathrm{OD} 560 \mathrm{~nm}=1)$.

Optical density of cyanobacterial cell suspension is directly related to its cellmass ornumber and the growth is measured by turbidity (spectrophotometrically at $560 \mathrm{~nm}$ ). The BG-11 medium composed of $\mathrm{g} / \mathrm{L}$ $\left(\mathrm{NaNO}_{3}-1.5, \mathrm{~K}_{2} \mathrm{HPO}_{4}-0.04, \mathrm{MgSO}_{4} .7 \mathrm{H}_{2} \mathrm{O}-0.075\right.$, $\mathrm{CaCl}_{2} .2 \mathrm{H}_{2} \mathrm{O}-0.036$, Citric acid - 0.006, Ferric ammonium citrate - 0.006, EDTA (disodium salt) - 0.001, $\mathrm{Na}_{2} \mathrm{CO}_{3}-0.02$, agar - 10.0), distilled water - 1.0 L, trace metal mix A5 - $1.0 \mathrm{~mL}$; (composition of trace metal mix A5 g/L - $\mathrm{H}_{3} \mathrm{BO}_{3}-2.86, \mathrm{MnCl}_{2} .4 \mathrm{H}_{2} \mathrm{O}$ $1.81, \mathrm{ZnSO}_{4} .7 \mathrm{H}_{2} \mathrm{O}-0.222, \mathrm{NaMoO}_{4} .5 \mathrm{H}_{2} \mathrm{O}-0.39$, $\mathrm{CuSO}_{4} .5 \mathrm{H}_{2} \mathrm{O}-0.079, \mathrm{Co}\left(\mathrm{NO}_{3}\right)_{2} .6 \mathrm{H}_{2} \mathrm{O}-0.04$, distilled water-1.0 L). The $\mathrm{pH}$ of the medium was adjusted to 7.0 using $1 \mathrm{~N} \mathrm{NaOH}$. N.muscorum from BG-11 medium was subcultured in fermented $100 \%$ kitchen waste water in $1 \mathrm{~L}$ flask and allowed to grow for 2 weeks until the OD at $560 \mathrm{~nm}$ reached 1 (OD560nm > 1). This stock was then used as N.muscorum inoculum for the experiments in $25 \mathrm{~L}$ cement tanks at $30^{\circ} \mathrm{C}$ under 2500 lux of illumination in a $12 \mathrm{~h}$ photoperiod. A complete randomized design (CRD) was carried out using 3 treatments, each performed in triplicates.

Initial physico-chemical properties of the waste water were measured before inoculating with N.muscorum. The control tanks consisted of the $25 \mathrm{~L}$ of BG-11 medium. The treatments were $100 \%$ kitchen waste water and $75 \%$ kitchen waste water $+25 \%$ tap water inoculated with N.muscorum culture. To avoid the contamination $10 \mu \mathrm{g} / \mathrm{ml}$ neomycin is supplemented before inoculating N.muscorum. The initial OD of each tank was 0.30. The experimental and control flasks were cultured for 15 days with continuous aeration at $32^{\circ} \mathrm{C} \pm 1^{\circ} \mathrm{C}$. Samples were collected for every 3 days and analyzed for their physicochemical properties viz. temperature, $\mathrm{pH}$, DO, BOD, COD, $\mathrm{NH}_{3}-\mathrm{N}, \mathrm{NO}_{3}-\mathrm{N}, \mathrm{NO}_{2}-\mathrm{N}$, TP and TKN. As the values of waste water met the standards of safe discharge on $15^{\text {th }}$ day of experiment the experiment was terminated. The biomass of the N.muscorum was separated by filtration using 120 $\mu \mathrm{m}$ plankton net. The weight was determined using a monopan electronic balance. The values obtained were subjected to statistical analysis.

\section{RESULTS AND DISCUSSION}

After completing the 15 days of experimental period there was a significant change in the physical and chemical properties of the waste water. The percent removal of the nutrients from waste water ranged between 50-98 in different treatments being minimum in BG-11 medium and maximum in $75 \%$ kitchen waster medium. All media showed an increase in $\mathrm{pH}$ during the experimental period, consistent with usual behavior of blue green algal cultures. A large increase in DO occurred in both waste water media $(100 \% \mathrm{KW}$ and $75 \% \mathrm{KW})$ as a result of aeration. 
Aeration is one of the most elemental technique frequently employed in the improvement of physical and chemical characteristics of water. Aeration improves the quality of water by supplying deficient oxygen, rescuing the free carbon dioxide $\left(\mathrm{CO}_{2}\right)$ and eliminating much of hydrogen disulphide $\left(\mathrm{H}_{2} \mathrm{~S}\right)$ and other odours from the waste water. Removal of $\mathrm{H}_{2} \mathrm{~S}$ would facilitate the optimal growth of cyanobacterial which used $\mathrm{H}_{2} \mathrm{O}$ instead of $\mathrm{H}_{2} \mathrm{~S}$ as a source of electrons and hydrogen for fixing $\mathrm{CO}_{2}$ (www.ucmp.berkley. edu). The optimum level of DO for algal culture in water is normally more than $5 \mathrm{mg} /$ liter ${ }^{12)}$. The final DO in waste water after cultivating the N.muscorum was (6.12 to $6.80 \mathrm{mg} /$ liter) (Fig. 1).

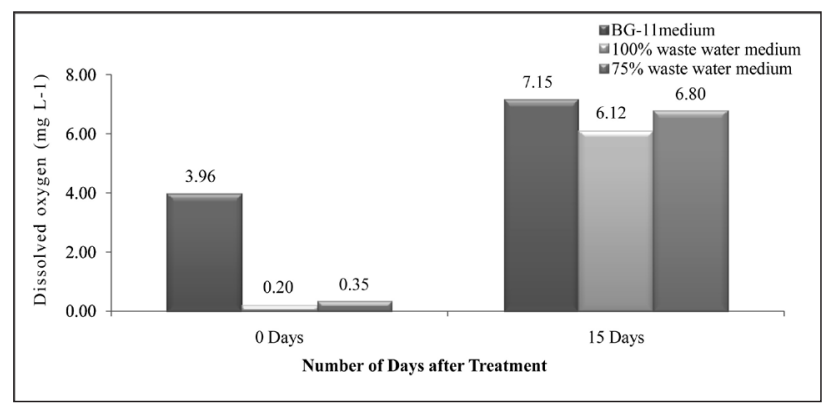

Fig. 1 Changes in dissolved oxygen

The initial level in the BG-11 medium was high since it was prepared using tap water containing considerable amount of DO, $75 \%$ waste water medium contained $25 \%$ tap water resulting in slightly elevated DO level compared to $100 \%$ waste water medium. For $100 \%$ and $75 \%$ waste water, the BOD decreased by $71.9 \%$ and $68.6 \%$ respectively (Fig. 2 ).

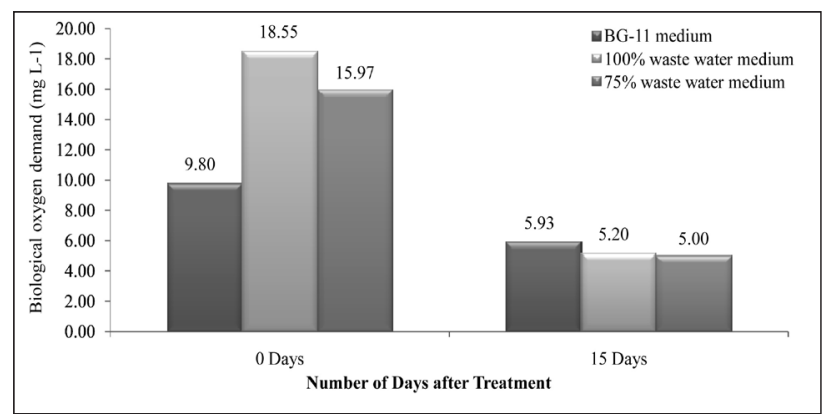

Fig. 2 Changes in biological oxygen demend

The chemical composition of BG-11 medium resulted in low BOD initially since it contained no significant amount of bio-degradable organic compounds such as protein, carbohydrate or fat. The present study showed a larger decrease in BOD during N.muscorum cultivation using kitchen waste water than the earlier reports by Chuntapa et $\mathrm{al}^{13)}$ with $100 \%$ waste water. The COD values decreased dramatically (73.1\% and 73.6\%) (Fig. 3).

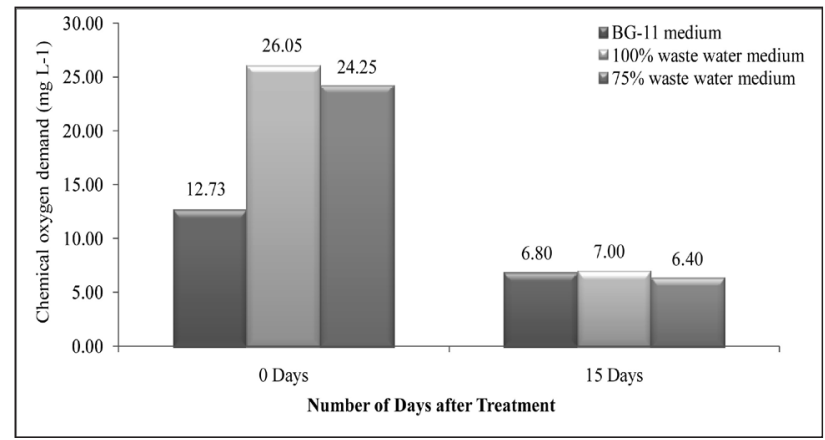

Fig. 3 Changes in chemical oxygen demand

The present findings on COD are in consistence with the earlier findings of Promya and Traichaiyaporn ${ }^{14)}$. As the waste water was collected directly from the kitchen outlet it exhibited low BOD and COD values compared to the values of stagnated waste water. To reduce the concentrations of phosphorous and nitrogen contaminants, the water was further diluted.

The total ' $\mathrm{P}$ ' levels in all three media (BG-11, $100 \%$ and $75 \%$ waste water medium) were initially high $4.7-5.5 \mathrm{mg} / \mathrm{L}$ and decreased nearly by 50.1 , $51.1 \%$ and 51.0 respectively (Fig. 4).

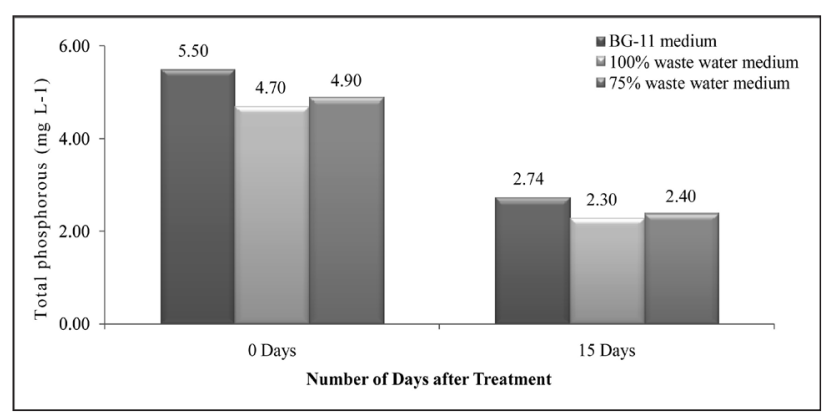

Fig. 4 Changes in total phosphorus

After cultivation of N.muscorum the $100 \% \mathrm{KW}$ and $75 \% \mathrm{KW}$ met the standards of safe discharge for BOD, COD, TP $(<20 \mathrm{mg} / \mathrm{L} ;<120 \mathrm{mg} / \mathrm{L} ;<2.4 \mathrm{mg} / \mathrm{L}$ respectively). There were significant levels of $\mathrm{NH}_{3}$ $\mathrm{N}$ initially in $100 \%$ and $75 \% \mathrm{KW}$ (Fig. 5). Algae prefer to use $\mathrm{NH}_{3}-\mathrm{N}$ than $\mathrm{NO}_{3}-\mathrm{N}$ and the optimal concentration range of nitrogen for algal growth is 1.3-6.5 mg/L ${ }^{15)}$. After 15 days of cultivation the $\mathrm{NH}_{3}$ $\mathrm{N}$ levels dropped dramatically by $94.4 \%$ and $92.8 \%$ for $100 \% \mathrm{KW}$ and $75 \% \mathrm{KW}$ respectively to those with in the allowable discharge limit for $\mathrm{NH}_{3}-\mathrm{N}(<1.4$ $\mathrm{mg} / \mathrm{L}$ ) as per Indian Council of Medical Research. These are similar to those in other studies where 54\% reduction was achieved ${ }^{16)}$. 


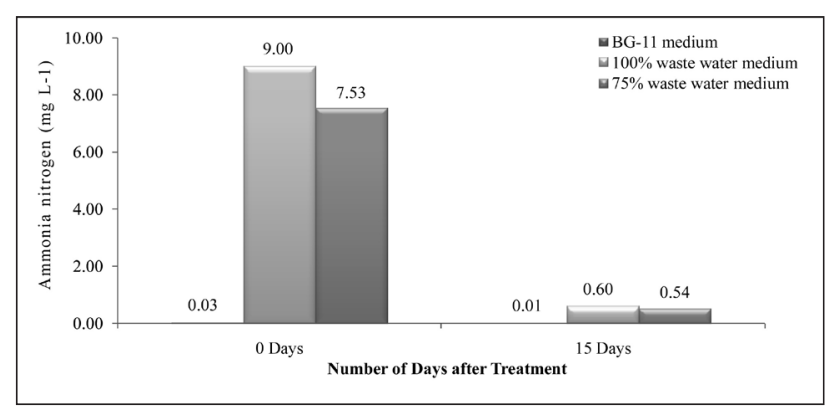

Fig. 5 Changes in ammonia nitrogen

The initial level of $\mathrm{NO}_{3}-\mathrm{N}$ in $\mathrm{BG}-11$ was high as it was the sole source of nitrogen. The $100 \% \mathrm{KW}$ and $75 \% \mathrm{KW}$ contained 4.10 and $3.72 \mathrm{mg} / \mathrm{L}$ respectively (Fig. 6) which reduced by $98 \%$ in both by cultivation of N.muscorum to meet the standards of safe discharge $(<0.7 \mathrm{mg} / \mathrm{L})$.

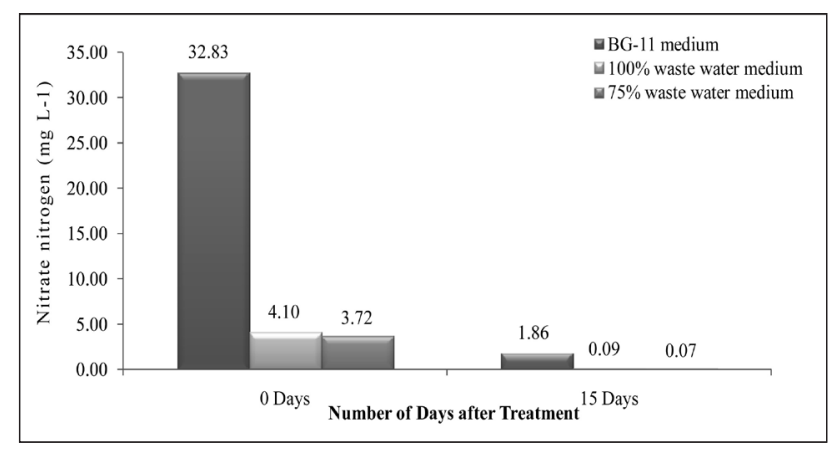

Fig. 6 Changes in nitrate nitrogen

In the present study $\mathrm{NO}_{2}-\mathrm{N}$ in all media was in the limits of 0.003 to $0.01 \mathrm{mg} / \mathrm{L}$ hence it was not considered as identifiable source of nutrient. Total kjeldhal nitrogen is the sum of organic nitrogen and ammonia nitrogen. Kitchen waste water contained significant amount of both organic and ammonia nitrogen so the initial total kjeldhal nitrogen was high $(21.5$ and $20.0 \mathrm{mg} / \mathrm{L}$ for $100 \%$ and $75 \%$ waste water medium respectively) (Fig. 7). Culturing of N.muscorum in kitchen waste water resulted in $95 \%$ decrease in TKN for both $100 \%$ and $75 \% \mathrm{KW}$ and the resulting water was improved to with in the discharge limit of $<50 \mathrm{mg} / \mathrm{L}$.

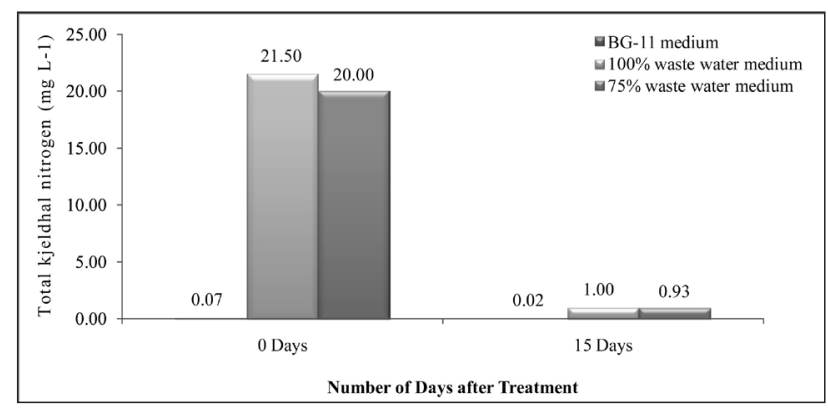

Fig. 7 Changes in total kjeldhal nitrogen

In the present study the tap water is used as a source for dilution of $100 \%$ wate water to $75 \%$. The amount of $\mathrm{P}$ and $\mathrm{N}$ present in the tap water is the reason for not obtaining three fourths of the values in $75 \%$ waste water after dilution.

The $100 \%$ waste water medium was nearly as effective as BG-11 medium in biomass production (0.83 and $0.85 \mathrm{~g} / \mathrm{L}$ respectively) (Fig. 8).

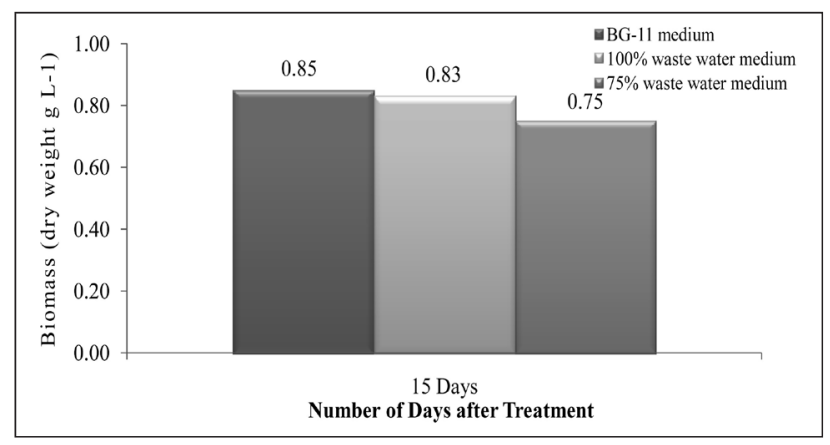

Fig. 8 Production of biomass

The biomass production in the present study is more compared to the earlier reports of $0.50 \mathrm{~g} / \mathrm{L}{ }^{17)}$. The waste water treatment can be achevied by biological, physical and chemical processes. A physical process usually treats suspended rather than dissolved pollutants. Chemical treatment is often used for removal of nitrogen and phosphorous pollutants by precipitation. Compared to engineering based technological approaches, the phytoremediation technique currently being employed effectively. Phytoremediation ensures quality with low nutrient content in treated waste water. In contrast to physical and chemical process phytoremediation produces smaller sludge and occurs at ambient temperature. It is of high sustainability, require low input in energy and manpower, and offer possibilities of carbon sequestration in biomass as well as the recycling of materials and matter ${ }^{18)}$.

In the present study an attempt had been made to compare the biomass production of N.muscorum at $100 \%$ and $75 \%$ dilutions of kitchen waste water and to know the percent of nutrients removed in two different dilutions after harvesting the biomass. Improvement in water quality is assessed by the ability of a process to reduce nutrient matter especially nitrogen and phosphorous. In the present study culturing of N.muscorum in waste water with high nutrient matter dramatically reduced nitrogen and phosphorous levels to ensure the safe discharge besides the production of useful product such as nitrogen fixing blue green algae as a source of biofertilizer.

\section{CONCLUSION}

Results of the present study proved that waste water obtained from piligrim centre can form a 
best nutritional media for large scale cultivation of nitrogen fixing cyanobacteria with low cost. The technique can be exploited for commercial production of biofertilisers which inturn is useful in treatment of domestic waste water. The biotechnological importance and advantage of using N.muscorum for waste water treatment was promising in removal of nitrogen and phosphorous nutreints from the waste water to the extent to meet the safe discharge limits in India.

ACKNOWLEDGEMENTS : We acknowledge the financial assistance from the University Grants Commission (UGC), New Delhi, in the form of Major Research Project (Project No. F.34-195/2008 (SR)).

\section{REFERENCES}

1) Lem, N.W. and Glick, B.R.: Biotechnological uses of cyanobacteria., Biotech Adv, Vol. 3, pp. 195-208, 1985.

2) Promya, J., Traichaiyaporn, S. and Deming, R.L.: Phytoremediation of domestic and industrial wastewater by S. platensis (Nordstedt) Geiteler. Proc. 40th Western Reg'l. Meeting, Am. Chem. Soc, California, 22-25 January 2006.

3) Phang, S.M., Miah, M.S., Yoeh, B.G. and Hashim, M.A.: Spirulina cultivation in digested sago starch factory waste water, J App phycol, Vol. 12, pp. 395-400, 2000.

4) Martinez, M.E., Sanchez, S., Jimenez, J.M., Yous, E.I. and Munoz, F.L.: Nitrogen and phosphorus removal from urban wastewater by the microalga Scenedesmus obliquus, Bioresource Technol, Vol. 73, pp. 263-272, 2000.

5) Dumas, A., Laliberte, G., Lessard, P. and De La Noüe, J.: Biotreatment of fish farm effluents using cyanobacterium Phormidium bohneri, Aqucult Engng, Vol. 7, pp. 57-68, 1998.

6) Ogbonna, J.C., Yoshizawa, H. and Tanaka, H. : Treatment of high strength organic waste water by a mixed culture of photosynthetic microorganisms, J App phycl, Vol. 12, pp. 277284, 2000.

7) Ponsano, E.H.G., Lacava, P.M. and Pinto, M.F.: Chemical composition of Rhodocyclus gelatinosus biomass produced in poultry slaughter waste water, Braz Arc Biol and Technol, Vol. 46, No. 2, pp. 1-11, 2003.

8) APHA: Standard methods for analysis of water and wastewater, $18^{\text {th }}$ Ed, American Public Health Association, Inc, Washington DC, 1992.

9) Traichaiyaporn, S.: Water quality analysis (a textbook in Thai), Department of Biology, Faculty of Science, Chiang Mai University, 2000.

10) Boshoff, G.A., Duncan, J.R. and Rose, P.D.: An algalbacterial integrated ponding system for the treatment of mine driange waters, J App Phycol, Vol. 8, No. 4-5, pp. 442-449, 1996.

11) Rippka, R., Deruelles, J., Waterbury, J.B., Herdman, M. and Stanier, R.Y.: Generic assignments, strain histories and properties of pure cultures of cyanobacteria. J. Gen. Microbiol, Vol 111, pp 1-61, 1979

12) Marquez, F.: Inhibitory effect of oxygen accumulation on the growth of S. platensis, Biotechnol Lett, Vol. 17, pp. 225-228, 1995.

13) Chuntapa, B., Powtongsook, S. and Menasveta, P.: Water quality control using $S$. platensis in shrimp culture tanks, Aquaculture, Vol. 220, pp. 355-366, 2003.
14) Promya, J., and Traichaiyaporn, S.: Water quality improvement of effluent from pig manure biogas digester by the culture of S. platensis (Nordstedt) Geiteler, J Sci Fac CMU, Vol. 30, pp. 95-101, 2003.

15) Chevalier, P., Proulx, D., Lessard, P., Vincent, W.F. and De La Noüe, J.: Nitrogen and phosphorous removal by high latitude mat forming cyanobacteria for potential use in teritiary waste water treatment, J Appl Phycol, Vol. 12, pp. 105-112, 2000.

16) An, J.Y., Sim, S.J., Lee, J.S. and Kim, B.K.: Hydrocarbon production from secondarily treated piggery wastewater by the green alga Botryococcus braunii, J Appl Phycol, Vol. 15, pp. 194-199, 2003.

17) Chourit, W., Thanahuset, P., Thong Pradista, J., Sasaki, K. and Noparatnaraporn, N.: Identification and cultivation of photosynthetic bacteria in waste water from concentrated latex processing factory, Biotechnol Lett, Vol. 24, No. 13, pp. 1055$1058,2002$.

18) Vanek, T. and Schwitzguebel, J.P.: Phytoremediation inventory, Report of COST Action 837, UOCHB AVCR, Praque, 2003.

(Received December 17, 2009) 